\title{
Axillary lymph node dose with tangential whole breast radiation in the prone versus supine position: a dosimetric study
}

Kara Lynne Leonard ${ }^{1 *+}$, David Solomon ${ }^{1+}$, Jaroslaw T Hepel ${ }^{2}$, Jessica R Hiatt ${ }^{2}$, David E Wazer ${ }^{1,2}$ and Thomas A DiPetrillo ${ }^{1,2}$

\begin{abstract}
Background: Prone breast positioning reduces skin reaction and heart and lung dose, but may also reduce radiation dose to axillary lymph nodes (ALNs).

Methods: Women with early stage breast cancer treated with whole breast irradiation (WBI) in the prone position were identified. Patients treated in the supine position were matched for treating physician, laterality, and fractionation. Ipsilateral breast, tumor bed, and Level I, II, and III ALNs were contoured according to the RTOG breast atlas. Clips marking surgically removed sentinel lymph nodes (SLN)s were contoured. Treatment plans developed for each patient were retrospectively analyzed. V90\% and V95\% was calculated for each axillary level. When present, dose to axillary surgical clips was calculated.

Results: Treatment plans for 46 women (23 prone and 23 supine) were reviewed. The mean $\mathrm{V} 90 \%$ and $\mathrm{V} 95 \%$ of ALN Level I was significantly lower for patients treated in the prone position ( $21 \%$ and $14 \%$, respectively) than in the supine position ( $50 \%$ and $37 \%$, respectively) ( $p<0.0001$ and $p<0.0001$, respectively). Generally, Level II \& III ALNs received little dose in either position. Sentinel node biopsy clips were all contained within axillary Level I. The mean V95\% of SLN clips was 47\% for patients treated in the supine position and $0 \%$ for patients treated in the prone position $(p<0.0001$ ). Mean V90\% to SLN clips was $96 \%$ for women treated in the supine position but only $13 \%$ for women treated in the prone position.

Conclusions: Standard tangential breast irradiation in the prone position results in substantially reduced dose to the Level I axilla as compared with treatment in the supine position. For women in whom axillary coverage is indicated such as those with positive sentinel lymph node biopsy who do not undergo completion axillary dissection, treatment in the prone position may be inappropriate.
\end{abstract}

Keywords: Breast cancer, Prone, Axillary lymph nodes, Radiation, ACOSOG Z0011

\section{Background}

The eight-year results of the ACOSOG Z0011 study evaluating locoregional recurrence after sentinel lymph node dissection (SLND) with or without axillary lymph node dissection (ALND) in patients with positive sentinel lymph nodes suggest that completion ALND may be unnecessary for selected early stage breast cancer patients $[1,2]$. Patients treated on ACOSOG Z0011 received

\footnotetext{
* Correspondence: karalynne.kerr@gmail.com

${ }^{\dagger}$ Equal contributors

'Department of Radiation Oncology, Tufts Medical Center, Box \#593 800Washington St, Boston, MA 02111, USA

Full list of author information is available at the end of the article
}

whole breast irradiation (WBI) with tangents in the supine position. Whole breast irradiation provides moderate radiation dose to the Level I and II axillary lymph nodes (ALN)s and to the region of the sentinel node [313]. If one considers that modest radiation doses to the axilla have clinical impact, the potentially practicealtering implications of ACOSOG Z0011 may reflect the importance of adequate dosing of these ALNs for sentinel node positive patients who have not had axillary dissection.

Recently, prone breast positioning for WBI has become more popular in efforts to decrease radiation dose to the

\section{Ciomed Central}


a.
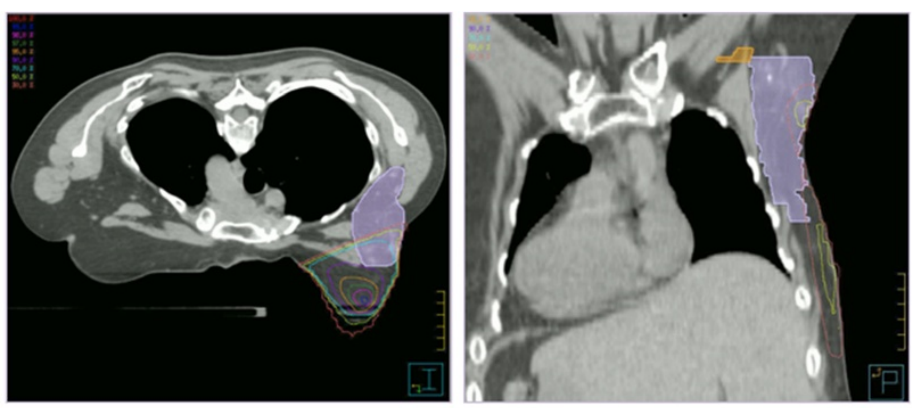

b.
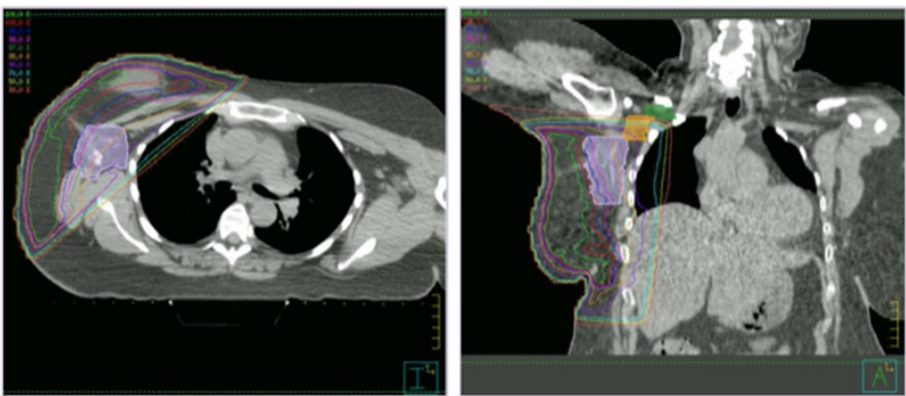

Figure 1 Axial and coronal images of Level I contoured (violet) for a patient treated in the (a) prone and (b) supine position.

heart and lungs and to decrease acute skin reaction in women with pendulous breasts $[9,14-17]$ while maintaining acceptable long-term outcomes [18]. Treatment planning studies have demonstrated the dosimetric benefits of prone breast irradiation for all women, regardless of breast size [19]. Prone positioning increases the anatomic distance of the breast from the heart and lungs, eliminates the bolus effect created by the inframammary fold, and improves dose homogeneity as compared to WBI in the prone position. Recent work has shown decreased coverage of the ALNs in the prone position when treatment plans were created for each patient in both the prone and supine position [9]. The current work explores dosing to axillary lymph nodes in patients thought to be ideal candidates for prone positioning.

\section{Methods}

Forty-six women with early stage breast cancer treated from 2009-2011 in the Departments of Radiation Oncology at our institution with standard tangential WBI in the prone or supine were identified. The 23 patients treated in the prone position were identified as ideal candidates for treatment in the prone position prior to or at the time of simulation for a variety of reasons including

Table 1 Anatomic boundaries of the ipsilateral breast and axillary lymph node Levels I-III as defined by the Radiation Therapy Oncology Group (RTOG) contouring atlas [21]

\begin{tabular}{|c|c|c|c|c|c|c|}
\hline & Cranial & Caudal & Medial & Lateral & Anterior & Posterior \\
\hline Breast & $\begin{array}{l}\text { Clinical reference } \\
\text { and second rib } \\
\text { insertion }\end{array}$ & $\begin{array}{l}\text { Clinical reference } \\
\text { and loss of } C T \\
\text { apparent breast }\end{array}$ & Sternal-rib junction & $\begin{array}{l}\text { Clinical reference } \\
\text { and mid axillary line. } \\
\text { Excludes latissimus } \\
\text { dorsi }\end{array}$ & Skin & $\begin{array}{l}\text { Excludes pectoralis } \\
\text { muscles, chestwall } \\
\text { muscles, ribs }\end{array}$ \\
\hline Level I & $\begin{array}{l}\text { Axillary vessels } \\
\text { crossing lateral } \\
\text { edge of } \\
\text { pectoralis minor }\end{array}$ & $\begin{array}{l}\text { Pectoralis major } \\
\text { insertion into ribs }\end{array}$ & $\begin{array}{l}\text { Axillary vessels } \\
\text { crossing lateral } \\
\text { edge of pectoralis } \\
\text { minor }\end{array}$ & $\begin{array}{l}\text { Medial border of } \\
\text { latissimus dorsi }\end{array}$ & $\begin{array}{l}\text { Plane defined } \\
\text { by the anterior } \\
\text { surface of pectoralis } \\
\text { major and } \\
\text { latissimus dorsi }\end{array}$ & $\begin{array}{l}\text { Anterior surface of } \\
\text { subscapularis }\end{array}$ \\
\hline Level ॥ & $\begin{array}{l}\text { Axillary vessels } \\
\text { crossing medial } \\
\text { edge of } \\
\text { pectoralis minor }\end{array}$ & $\begin{array}{l}\text { Axillary vessels } \\
\text { crossing lateral } \\
\text { edge of pectoralis } \\
\text { minor }\end{array}$ & $\begin{array}{l}\text { Medial border of } \\
\text { pectoralis minor }\end{array}$ & $\begin{array}{l}\text { Lateral border of } \\
\text { pectoralis minor }\end{array}$ & $\begin{array}{l}\text { Anterior surface of } \\
\text { pectoralis minor }\end{array}$ & $\begin{array}{l}\text { Ribs and intercostal } \\
\text { muscles }\end{array}$ \\
\hline Level III & $\begin{array}{l}\text { Pectoralis minor } \\
\text { insertion on } \\
\text { corocoid process }\end{array}$ & $\begin{array}{l}\text { Axillary vessels } \\
\text { crossing medial } \\
\text { edge of pectoralis } \\
\text { minor }\end{array}$ & Thoracic inlet & $\begin{array}{l}\text { Medial border of } \\
\text { pectoralis minor }\end{array}$ & $\begin{array}{l}\text { Posterior surface } \\
\text { of pectoralis major }\end{array}$ & $\begin{array}{l}\text { Ribs and intercostal } \\
\text { muscles }\end{array}$ \\
\hline
\end{tabular}


large breast size $(n=9)$, to limit lung dose $(n=11)$, or to limit heart dose $(n=3)$. Those treated prone for large breast size had a breast volume of $1000 \mathrm{~mL}$ or greater, those treated prone to limit lung dose would have had $2.5 \mathrm{~cm}$ or greater of cross-sectional lung included within a standard tangent, and those treated prone to limit heart dose had an anteriorly located left anterior descending (LAD) artery. Twenty-three patients treated in the supine position consecutively during the same time period (2009 - 2011) were chosen for comparison and matched for treating physician, laterality, and fractionation (conventional vs. Canadian fractionation [20]). All patients underwent Computed Tomography (CT) based simulation using a Philips Brilliance Big Bore 16slice CT scanner (Philips Healthcare, Andover, MA). Patients treated prone were simulated using the Bionix Prone Breast System (Bionix Radiation Therapy, Toledo, $\mathrm{OH})$ and patients treated supine were simulated using the Accufix Quest Breast Board (Q-Fix Systems, Wyckoff, NJ). Three dimensional (3D) treatment planning for all patients was performed using the Pinnacle ${ }^{3}$ (version $8.0 \mathrm{~m}$, Philips Medical Systems, Cleveland, $\mathrm{OH}$ ) treatment planning system. Conventional and prone breast tangential fields were designed to encompass the whole breast while minimizing dose to lung and heart without special attention to ALN coverage as confirmed by the treating physician. No patients were treated with "high tangents."

Planning CT scans were retrospectively contoured to identify ipsilateral breast tissue, tumor bed, and Level I, II, and III ALNs according to the anatomic boundaries set by the Radiation Therapy Oncology Group (RTOG) contouring atlas [21], as shown in Figure 1. Table 1 delineates the boundaries of the levels in all 6 directions. When present, clips marking sentinel lymph nodes (SLN) removed during sentinel node biopsy were also contoured. Ipsilateral breast and ALN Level I-III volumes were compared between the two groups using the $t$-test.

Treatment plans for each patient were retrospectively analyzed to evaluate dose to the tumor bed, breast, and individual nodal levels. The mean dose to the ipsilateral breast as well as the volume of breast tissue and tumor bed receiving 95\% (V95\%) of the prescribed dose were calculated. The mean dose and the volume receiving 50\% (V50\%), 90\% (V90\%), and 95\%, of the prescribed dose were then calculated for each axillary level. Dose to axillary surgical clips was similarly calculated, when applicable. Mean dose, V90\%, V95\% of axillary Level I were compared between those treated in the prone position

Table 2 Summary of patient characteristics

\begin{tabular}{|c|c|c|c|c|}
\hline & & Supine $(n=23)$ & Prone $(n=23)$ & Comparison (two-tailed unpaired t-test) \\
\hline & Mean Age $(y) \pm S D^{*}$ & $65 \pm 12$ & $57 \pm 9$ & \\
\hline & Side: Left/Right & $13 / 10$ & $13 / 10$ & \\
\hline & Mean breast volume $\left(\mathrm{cm}^{3}\right) \pm S D$ & $841 \pm 369$ & $793 \pm 462$ & $p=0.70\left(\mathrm{Cl}^{\dagger}=-200\right.$ to 296$)$ \\
\hline \multirow[t]{3}{*}{ T Stage } & Tis & 7 & 5 & \\
\hline & $\mathrm{T} 1$ & 12 & 17 & \\
\hline & $\mathrm{T} 2$ & 4 & 1 & \\
\hline N Stage & NO & 21 & 21 & \\
\hline N1 & 2 & 2 & & \\
\hline \multirow[t]{3}{*}{ Dissection Status: } & No nodal biopsy & 5 & 6 & \\
\hline & Sentinel node biopsy & 18 & 15 & \\
\hline & Completion axillary dissection & 0 & 2 & \\
\hline \multirow[t]{3}{*}{ Radiation Dose } & 46 Gy in 23 fractions & 8 & 8 & \\
\hline & 42.5 Gy in 16 fractions & 9 & 9 & \\
\hline & 50-50.4 Gy in 25-28 fractions & 6 & 6 & \\
\hline \multirow[t]{4}{*}{ Mean Axillary Volume } & Level I $\left(\mathrm{cm}^{3}\right) \pm \mathrm{SD}$ & $106 \pm 38$ & $98 \pm 35$ & $p=0.46(\mathrm{Cl}=-30$ to 14$)$ \\
\hline & Level II $\left(\mathrm{cm}^{3}\right) \pm S D$ & $21 \pm 6$ & $24 \pm 7$ & \\
\hline & Level III $\left(\mathrm{cm}^{3}\right) \pm \mathrm{SD}$ & $9 \pm 3$ & $10 \pm 5$ & $p=0.13(\mathrm{Cl}=-0.87$ to 6.9$)$ \\
\hline & & & & $p=0.42(\mathrm{Cl}=-3.5$ to 1.5$)$ \\
\hline
\end{tabular}

${ }^{*} \mathrm{SD}=$ standard deviation; ${ }^{\dagger} \mathrm{Cl}=$ Confidence interval. 
and those treated in the supine position using a twotailed unpaired $t$-test for difference of means. For Level $\mathrm{I}$, the relative dose-volume histograms $(\mathrm{DVH})$ were generated for all patients and the mean DVHs were compared among the prone and supine groups.

\section{Results}

Table 2 provides patient characteristics for the prone and supine cohorts. In general, patients treated in the prone position were younger. The mean ipsilateral breast volumes and axillary Level I, II, and III nodal volumes (and standard deviations) are also shown in Table 2. As expected, breast volumes tended to be larger in the prone position than in the supine position, but this difference did not reach statistical significance. There was no difference in volumes contained within the axillary nodal levels between the two groups.

Doses (and standard deviations) delivered to the ipsilateral breast, tumor bed, and all axillary levels are provided in Table 3a. Mean breast dose and V95\% of ipsilateral breast and tumor bed did not differ significantly between those treated in the prone position and those treated in the supine position. Only axillary Level I received appreciable dose in both groups of patients. Generally, Level II \& III ALNs did not receive a significant portion of prescribed dose in either position.

Within each group, there was substantial variation in the dose coverage of axillary Level I. Among women treated in the prone position, V95\% was less than 10\% in 14 women and was $0 \%$ in 6 women. Figure 2 compares the mean Level I DVH for the prone and supine groups. The mean dose to Level I was $36 \%$ of prescription for patients treated in the prone position, significantly less than the $66 \%$ of prescription for patients treated in the supine position $(p<0.0001 ; 95 \%$ confidence interval $=$ $15 \%$ to $45 \%)$. Mean V95\% was lower in women treated in the prone position as compared to women treated in the supine position $(14 \%$ vs. $37 \% ; p<0.0001$; $95 \%$ confidence interval $=12 \%$ to $34 \%$ ).

Table 3 Summary of calculated volume and dose to (a) ipsilateral breast and tumor bed, to (b) axillary levels I, II, and III and to (c)sentinel lymph node (SLN) clips

\begin{tabular}{|c|c|c|c|c|}
\hline \multicolumn{5}{|c|}{ a) Dose to ipsilateral breast and tumor bed } \\
\hline & & Supine $(n=23)$ & Prone $(n=23)$ & Comparison (two-tailed unpaired t-test) \\
\hline \multicolumn{2}{|l|}{ Ipsilateral breast mean dose $(\%) \pm S D^{*}$} & $96 \pm 3.8$ & $95 \pm 1.8$ & $p=0.26\left(\mathrm{Cl}^{\dagger+}=-0.77\right.$ to2.8) \\
\hline \multicolumn{2}{|l|}{ V95\% ipsilateral breast } & $77 \pm 6.5$ & $74 \pm 5.3$ & $p=0.09(\mathrm{Cl}=-0.52$ to 6.5$)$ \\
\hline \multicolumn{2}{|l|}{ V95\% tumor bed } & $99 \pm 1.7$ & $98 \pm 4.6$ & $p=0.33(\mathrm{Cl}=-1.1$ to 3.1$)$ \\
\hline \multicolumn{5}{|l|}{ b) Dose to axillary volumes } \\
\hline \multirow[t]{3}{*}{ Mean dose (\%) \pm SD } & Level I & $66 \pm 20$ & $36 \pm 30$ & $p<0.0001(\mathrm{Cl}=15$ to 45$)$ \\
\hline & Level II & $6 \pm 15$ & $3 \pm 3$ & \\
\hline & Level III & $3 \pm 2$ & $<1 \pm 0.4$ & \\
\hline \multirow[t]{3}{*}{ Mean V95\% \pm SD } & Level I & $37 \pm 18$ & $14 \pm 19$ & $p<0.0001(\mathrm{Cl}=12$ to 34$)$ \\
\hline & Level II & 0 & 0 & \\
\hline & Level III & 0 & 0 & \\
\hline \multirow[t]{3}{*}{ Mean $\mathrm{V} 90 \% \pm \mathrm{SD}$} & Level I & $50 \pm 20$ & $21 \pm 25$ & $p<0.0001(\mathrm{Cl}=16$ to 43$)$ \\
\hline & Level II & $1 \pm 5$ & 0 & \\
\hline & Level III & 0 & 0 & \\
\hline \multirow[t]{3}{*}{ Mean V50\% \pm SD } & Level I & $67 \pm 19$ & $35 \pm 33$ & \\
\hline & Level II & $5 \pm 17$ & $<1 \pm 2$ & \\
\hline & Level III & 0 & 0 & \\
\hline \multicolumn{5}{|c|}{ c) Dose to sentinel lymph node $\left(\mathrm{SLN}^{\dagger}\right)$ clips } \\
\hline & & Supine $(n=9)$ & Prone $(n=7)$ & \\
\hline \multicolumn{2}{|l|}{ SNB clips in treatment field } & 9 & 2 & \\
\hline \multicolumn{2}{|l|}{ V95\% SLN clips \pm SD } & $47 \pm 43$ & $0 \pm 0$ & $p<0.0001(95 \% \mathrm{Cl}=29$ to 65$)$ \\
\hline \multicolumn{2}{|l|}{ SLN clips receiving $\geq 90 \%$ dose } & 8 & 1 & \\
\hline \multicolumn{2}{|l|}{ Mean dose to SLN clips $(\%) \pm S D$} & $95 \pm 5$ & $43 \pm 34$ & \\
\hline
\end{tabular}

${ }^{*} S D=$ standard deviation; ${ }^{\dagger} S L N=$ sentinel lymph node; ${ }^{+\dagger} \mathrm{Cl}=$ confidence interval. 


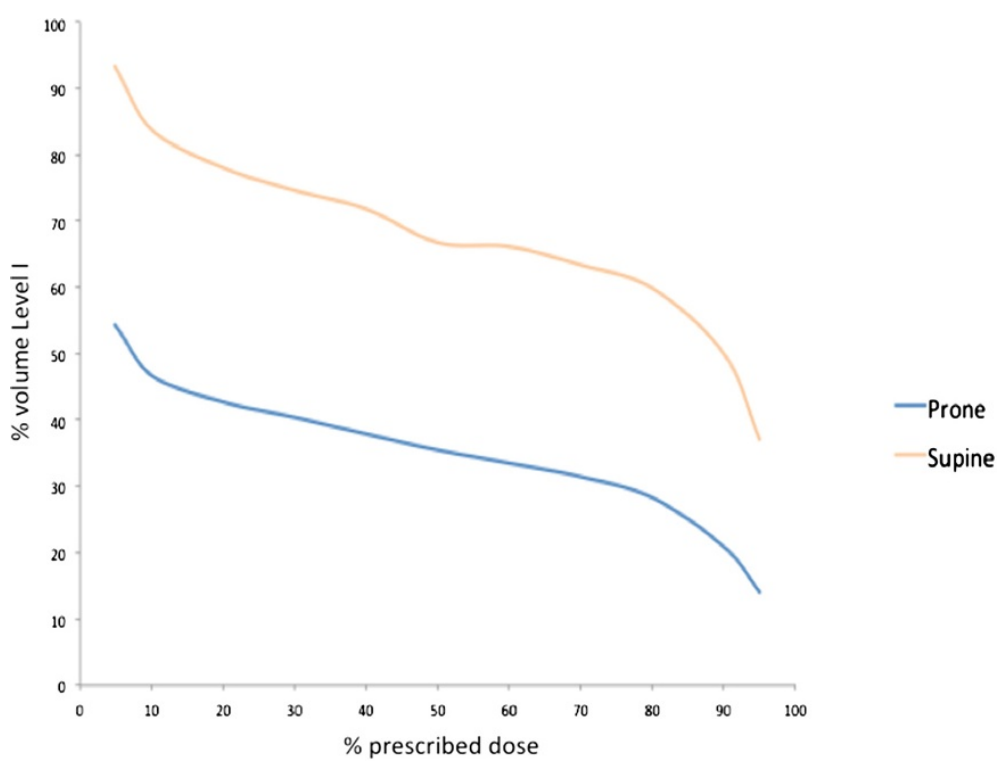

Figure 2 Comparison of mean DVH data for patients treated in the prone and supine position.

Sixteen patients (seven treated prone and nine treated supine) had axillary surgical clips placed at the time of SLN biopsy; all of the clips were located within axillary Level I. Only two of the seven patients treated in the prone position had clips within the tangential treatment field. However, all SLN clips in patients treated in the supine position were within the treatment field. As shown in Table 3c, mean V95\% of SLN clips was $0 \%$ for the seven patients treated in the prone position. Mean V95\% of SLN clips was $47 \%$ among patients treated in the supine position. The difference in mean V95\% between the two groups was statistically significant $(p<0.0001 ; 95 \%$ confidence interval $=29 \%$ to $65 \%$ ). At least $90 \%$ of prescribed dose was delivered to the clips in eight of nine patients treated supine (mean V90\% $=96 \%$ ), but in only one of seven patients treated prone (mean V90\% $=13 \%$ ).

\section{Discussion}

The recently published eight-year results of the American College of Surgeons Oncology Group (ACOSOG) Z0011 study showed no difference in axillary failure rates or overall survival in women with cT1-2 cN0 breast cancer with one or two positive sentinel nodes randomized to undergo no further axillary surgery versus completion axillary dissection $[1,2]$. The locoregional control was excellent (1.8\% failure) despite suspected residual disease in approximately $40 \%$ of these women. Per protocol, women in this study received adjuvant radiation therapy with standard tangential irradiation. Although there has been debate surrounding the contribution of radiation therapy to axillary control in these women, this was likely due to sterilization of micrometastatic disease by tangential radiation therapy. These findings have strong implications for the importance of adjuvant radiation therapy to provide dose to the lower axilla in women with positive sentinel lymph nodes who will not undergo completion axillary dissection. In fact, regional nodal irradiation has also been associated with improved survival [22], and improvements in locoregional control have translated into improvements in overall survival with extended follow-up [23].

Prone breast irradiation provides clear benefits in reducing skin toxicity for large breasted women and in reducing heart and ipsilateral lung dose for patients with unfavorable thoracic anatomy [9,14-18]. The present investigation suggests that axillary nodal coverage should also be considered when making the decision to treat women in the prone versus supine position. The data presented in this study suggest that irradiation in the prone position does not allow for the same coverage of axillary tissue as does irradiation in the supine position.

Although the classic anatomic boundaries of the axilla are well defined, the clinically relevant borders are not. There is substantial variation in definition of boundaries of the axilla used in radiotherapy treatment as outlined in Table 4. For the purpose of standardizing the borders of the axilla, the RTOG published a contouring atlas [21]. Perhaps contrary to classic teaching, recent literature (including the present study) suggests that standard tangential whole breast irradiation delivers the prescribed dose to only a portion of Level I of the axilla, particularly as defined by the RTOG. In the present study, only $37 \%$ of the Level I volume received $95 \%$ of the dose with standard tangential irradiation. It is not clear whether this level of coverage delivers sufficient dose for therapeutic treatment of axillary lymph nodes. 
Table 4 Review of the literature reporting boundaries of and dose to axillary Level I volumes and/or clips in patients undergoing tangential radiation therapy as part of breast conservation therapy

\begin{tabular}{|c|c|c|c|c|c|c|}
\hline Study & $\begin{array}{l}\text { Patients } \\
(n)\end{array}$ & Method & $\begin{array}{l}\text { Axillary } \\
\text { surgery }\end{array}$ & $\begin{array}{l}\text { Axillary } \\
\text { clips (n) }\end{array}$ & Borders of axillary Level I & Dose to Level I \\
\hline Krasin et al. [3] & 25 & $\begin{array}{l}2 \mathrm{D} \operatorname{sim} / 3 \mathrm{D} \\
\text { analysis }\end{array}$ & $\mathrm{ALND}^{*}$ & 16 & Not listed & $\begin{array}{l}\text { Mean dose }=32 \\
\text { Gy }(63.5 \%)\end{array}$ \\
\hline \multirow[t]{5}{*}{ Aristei et al. [4] } & 35 & $\begin{array}{l}2 \mathrm{D} \operatorname{sim} / 3 \mathrm{D} \\
\text { analysis }\end{array}$ & ALND & 35 & Caudal border: Inferior clip & $\mathrm{D}_{90} \%=6.75 \mathrm{~Gy}$ \\
\hline & & & & & $\begin{array}{l}\text { Cranial border: Axillary } \\
\text { vein and } 2^{\text {nd }} \text { clip }\end{array}$ & \\
\hline & & & & & $\begin{array}{l}\text { Medial border: Lateral border } \\
\text { of pectoralis minor }\end{array}$ & \\
\hline & & & & & Lateral border: Axillary vein & \\
\hline & & & & & Posterior border: Latissimus dorsi & \\
\hline \multirow[t]{3}{*}{ Takeda et al. [5] } & 44 & $2 \mathrm{D} \operatorname{sim} / 3 \mathrm{D}$ analysis & ALND & 44 & $\begin{array}{l}\text { Caudal border: Clip in latissimus } \\
\text { dorsi at inferior level of dissection }\end{array}$ & Median $V_{80} \%=30.5 \%$ \\
\hline & & & & & $\begin{array}{l}\text { Cranial border: Clip in the latissimus } \\
\text { dorsi at level of axillary vein }\end{array}$ & \\
\hline & & & & & $\begin{array}{l}\text { Posterior border: Clip in adjacent } \\
\text { to subscapularis vein }\end{array}$ & \\
\hline \multirow[t]{3}{*}{ Orecchia et al. [6] } & 15 & $3 \mathrm{D} C R T^{\dagger}$ & $\mathrm{SNB}^{+\dagger}$ & 15 & Caudal border: SNB clip & Mean dose $=48.7 \%$ \\
\hline & & & & & Cranial border Manubrium & $\pm 22 \%$ \\
\hline & 35 & 3D CRT & SNB & $\mathrm{N} / \mathrm{A}$ & $\begin{array}{l}\text { Caudal border: Between } 4^{\text {th }} \\
\text { and } 5^{\text {th }} \text { ribs }\end{array}$ & $V_{95} \%=51 \% \pm 16 \%$ \\
\hline \multirow[t]{2}{*}{ Reznik et al. [7] } & & & & & Cranial border: Axillary vein & Mean dose $=66 \% \pm 13 \%$ \\
\hline & & & & & Medial border: Pectoralis minor & \\
\hline \multirow[t]{6}{*}{ Reed et al. [8] } & 50 & 3D CRT & $32 \mathrm{SNB}$ & 50 & $\begin{array}{l}\text { Caudal border: Latissiumus dorsi } \\
\text { and clavipectoral-lattisimus fascia }\end{array}$ & $\begin{array}{l}\text { Mean } V_{95} \%=55 \% \\
\text { Median } V_{95} \%=53 \%\end{array}$ \\
\hline & & & 18 ALND & & $\begin{array}{l}\text { Cranial border: Most inferior axial } \\
\text { image of axillary artery/vein }\end{array}$ & \\
\hline & & & & & Medial border: Pectoralis minor & \\
\hline & & & & & $\begin{array}{l}\text { Lateral border: Medial aspect of } \\
\text { pectoralis seratus }\end{array}$ & \\
\hline & & & & & Anterior border: Pectoralis minor & \\
\hline & & & & & $\begin{array}{l}\text { Posterior border: Latissimus dorsi } \\
\text { and subscapularis }\end{array}$ & \\
\hline \multirow[t]{5}{*}{$\begin{array}{l}\text { Alonso-Basanta } \\
\text { et al. [9] }\end{array}$} & 20 & 3D CRT & Not reported & $\mathrm{N} / \mathrm{A}$ & $\begin{array}{l}\text { Caudal border: Origin of pectoralis } \\
\text { minor } 3^{\text {rd }}-5^{\text {th }} \text { ribs }\end{array}$ & $V_{95} \%<60 \%$ \\
\hline & & & & & $\begin{array}{l}\text { Cranial border: Pectoralis minor } \\
\text { insertion of the coracoid process }\end{array}$ & $\begin{array}{l}\text { Prone: Mean } \\
\text { dose = } 11.2 \mathrm{~Gy}\end{array}$ \\
\hline & & & & & Medial border: Pectoralis minor & $\begin{array}{l}\text { Supine: Mean } \\
\text { dose }=21 \mathrm{~Gy}\end{array}$ \\
\hline & & & & & Lateral border: Latissimus dorsi & \\
\hline & & & & & Posterior border: Latissimus dorsi & \\
\hline \multirow{3}{*}{$\begin{array}{l}\text { Schlembach } \\
\text { et al. [10] }\end{array}$} & 105 & 3D CRT & 65 SNB & 105 & Surgical clips & $85 \%$ of clips in the field \\
\hline & & & & & & Mean dose to clips $=98 \%$ \\
\hline & & & 39 ALND & & & \\
\hline $\begin{array}{l}\text { McCormick } \\
\text { et al. [11] }\end{array}$ & 45 & $2 \mathrm{D}$ & ALND & 45 & Surgical clips & $38 \%$ of clips in field \\
\hline
\end{tabular}




\begin{tabular}{|c|c|c|c|c|c|c|}
\hline Chung et al. [12] & 36 & $2 \mathrm{D}$ or $3 \mathrm{D} C \mathrm{CRT}$ & SNB & 36 & Surgical clips & $94 \%$ of clips in field \\
\hline \multirow[t]{6}{*}{ Present study } & 46 & 3D CRT & SNB & 7 prone & RTOG Atlas [20] & Prone: $V_{95} \%=14 \%$ \\
\hline & & & & 9 supine & & Mean dose $=36 \% \pm 31 \%$ \\
\hline & & & & & & Mean dose to clips $=43 \%$ \\
\hline & & & & & & Supine: $V_{95} \%=37 \%$ (supine) \\
\hline & & & & & & Mean dose $=66 \% \pm 20 \%$ \\
\hline & & & & & & Mean dose to clips $=95 \%$ \\
\hline
\end{tabular}

${ }^{*} A L N D=$ Axillary lymph node dissection; ${ }^{\dagger} 3 D C R T=$ Three dimensional conformal radiation therapy $;{ }^{++} S N B=$ Sentinel node biopsy.

Studies demonstrating similar coverage of axillary Level I with standard tangents have suggested that such coverage does not provide adequate doses to control residual microscopic disease in the axilla [3,7]. The present study suggests that the area of the axilla receiving fully dose (90-95\% of the prescribed dose) may contain the microscopic disease. In fact, the clinically important target tissue in the axilla has not yet been clearly defined. The 98\% locoregional control seen in ACOSOG Z0011 with SNLD alone suggests that standard tangential fields encompass the clinically relevant nodal tissue.

The location of clips placed during SNLD may represent the area at highest risk of harboring metastatic disease after SNLD alone. Certainly, we know that the sentinel node is the most likely to contain breast cancer metastases. The neighboring nodes may represent the next echelon for metastatic spread. Despite suboptimal coverage of the entire nodal volume, standard tangents provide substantial dose to the clips placed to mark the location of the sentinel lymph node as shown in this study as well as others $[8,10,12]$. However, for women treated in the prone position, the area marked by SNLD clips receives minimal radiation dose. This raises concern that treatment in the prone position may provide suboptimal coverage of the most clinically important axillary nodal areas.

The study by Stegman et al., which showed a 5 -year regional control rate of $98.4 \%$ in 245 patients treated with WBI in the prone position demonstrates that prone irradiation provides adequate adjuvant treatment for the pathologically negative axilla and for the positive axilla that has undergone a full Level 1, 2 axillary lymph node dissection [18]. This excellent axillary control rate is expected in a population of women comprised of $15 \%$ of patients with DCIS and 65\% of patients with pN0 disease. Importantly, all women with positive lymph nodes in the Stegman study underwent Level 1, 2 axillary lymph node dissection. The undissected node-positive population in the ACOSOG Z0011 is at substantially higher risk for regional failure and likely receives substantial benefit from standard tangential irradiation.
Results similar to ours were published by AlonsoBasanta et al., who reported on twenty patients simulated in both the prone and supine position [9]. The mean dose to the axilla was 11.2 Gy when patients were simulated in the prone position and 21 Gy when the same patients were simulated in the supine position. The authors stated that alternative positioning was warranted in eight of the twenty patients for anatomic reasons (i.e., breast size, lung dose), while in the present study, all twenty-three patients treated prone were determined to be ideal candidates for prone positioning by the treating radiation oncologist. Thus, the current investigation includes patients in whom such a dosimetric evaluation is most critical. Moreover, the present study includes the novel finding that tangential irradiation in the supine position provides significantly better coverage of sentinel lymph node tissue than tangential irradiation in the prone position.

The limitations of the present study include a small sample size and the inherent sample bias associated with retrospective trial design. Additionally, only a small number of patients had SNLD clips placed, limiting the analysis of radiation dose delivery to axillary clips. While care was taken to choose an appropriate supine match for each prone patient, differences may inherently exist between the two groups. Although there was no significant difference in mean breast size or mean axillary volume between the two groups, other differences may exist that could bias the results. For example, patients in the prone group are slightly younger than patients in the supine group.

\section{Conclusion}

Standard tangential breast irradiation in the prone position results in substantially reduced dose to the Level I axilla as compared with treatment in the supine position. For women in whom axillary coverage is indicated such as those with positive sentinel lymph node biopsy who do not undergo completion axillary dissection, treatment in the prone position may be inappropriate. For women with DCIS or those with a negative sentinel node biopsy, 
treatment in the prone position does result in good coverage of target breast tissue.

\section{Abbreviations}

ALN: Axillary lymph node; WBI: Whole breast irradiation; SLN: Sentinel lymph node; SLND: Sentinel lymph node dissection; ALND: Axillary lymph node dissection; CT: Commuted tomography; RTOG: Radiation Therapy Oncology Group; V90\%: Volume receiving $90 \%$ of the dose; V50\%: Volume receiving 50\% of the dose; V95\%: Volume receiving $95 \%$ of the dose; DVH: Dose volume histogram.

\section{Competing interests}

The authors declare that they have no competing interests.

\section{Authors' contributions}

KLL performed data collection, analysis and interpretation of data, was involved in drafting the manuscript and revising it critically for important intellectual content. DS performed data collection, analysis and interpretation of data, was involved in drafting the manuscript. JTH was involved in drafting the manuscript and revising it critically for important intellectual content. JRH was involved in analysis and interpretation of data. DEW made substantial contributions to conception and design of the study and revised in critically for important intellectual content. TAD was principally responsible for the conception and design of the study and revised in critically for important intellectual content. All authors read and approved the final manuscript.

\section{Author details}

${ }^{1}$ Department of Radiation Oncology, Tufts Medical Center, Box \#593 800Washington St, Boston, MA 02111, USA. ²Department of Radiation Oncology, Rhode Island Hospital, Warren Alpert School of Medicine of Brown University, Providence, RI, USA.

Received: 13 January 2012 Accepted: 30 April 2012

Published: 18 May 2012

\section{References}

1. Giuliano $A E$, McCall $L$, Beitsch $P$, et al: Locoregional recurrence after sentinel lymph node dissection with or without axillary dissection in patients with sentinel lymph node metastases: the American College of Surgeons Oncology Group Z0011 randomized trial. Ann Surg 2010, 252:426-433.

2. Giuliano $A E$, Hunt $K K$, Ballman $K V$, et al: Axillary dissection vs no axillary dissection in women with invasive breast cancer and sentinel node metastasis. JAMA 2011, 305:569-575.

3. Krasin M, McCall A, King S, et al: Evaluation of a standard breast tangent technique: A dose-volume analysis of tangential irradiation using threedimensional tools. Int J Radiat Oncol Biol Phys 2000, 47:327-333.

4. Aristei $C$, Chionne F, Marsella AR, et al: Evaluation of level I and II axillary nodes included in the standard breast tangential fields and calculation of the administered dose: Results of a prospective study. Int J Radiat Oncol Biol Phys 2001, 51:69-73.

5. Takeda A, Shigematsu N, Ikeda T, et al: Evaluation of novel modified tangential irradiation technique for breast cancer patients using dosevolume histograms. Int J Radiat Oncol Biol Phys 2004, 58:1280-1288.

6. Orecchia R, Huscher A, Leonardi MC, et al: Irradiation with standard tangential breast fields in patients treated with conservative surgery and sentinel node biopsy: Using a three-dimensional tool to evaluate the first level coverage of the axillary nodes. $\mathrm{Br} J$ Radiol 2005, 78:51-54.

7. Reznik J, Cicchetti MG, Degaspe B, et al: Analysis of axillary coverage during tangential radiation therapy to the breast. Int J Radiat Oncol Biol Phys 2005, 61:163-168.

8. Reed DR, Lindsley SK, Mann GN, et al: Axillary lymph node dose with tangential breast irradiation. Int J Radiat Oncol Biol Phys 2005, 61:358-364

9. Alonso-Basanta M, Ko J, Babcock $\mathrm{M}$, et al: Coverage of axillary lymph nodes in supine vs. prone breast radiotherapy. Int J Radiat Oncol Biol Phys 2009, 73:745-751.

10. Schlembach PJ, Buchholz TA, Ross Ml, et al: Relationship of sentinel and axillary Level I-II lymph nodes to tangential fields used in breast irradiation. Int J Radiat Oncol Biol Phys 2001, 51:671-678.

11. McCormick B, Botnick M, Hunt M, et al: Are the axillary lymph nodes treated by standard tangent breast fields?. J Surg Oncol 2002, 81:12-16.
12. Chung MA, DiPetrillo T, Hernandez $S$, et al: Treatment of the axilla by tangential breast radiotherapy in women with invasive breast cancer. Am J Surg 2002, 184:401-402.

13. Goodman RL, Grann A, Saracco P, et al: The relationship between radiation fields and regional lymph nodes in carcinoma of the breast. Int J Radiat Oncol Biol Phys 2001, 50:99-105.

14. Merchant TE, McCormick B: Prone position breast irradiation. Int J Radiat Oncol BiolPhys 1994, 30:197-203.

15. Formenti SC, Gidea-Addeo D, Goldberg JD, et al: Phase I-II trial of prone accelerated intensity modulated radiation therapy to the breast to optimally spare normal tissue. J Clin Oncol 2007, 25:2236-2242.

16. Griem KL, Fetherston $P$, Kuznetsova $M$, et al: Three-dimensional photon dosimetry: a comparison of treatment of the intact breast in the supine and prone position. Int J Radiat Oncol Biol Phys 2003, 57:891-899.

17. Kirby AM, Evans PM, Donovan EM, et al: Prone versus supine positioning for whole and partial-breast radiotherapy: A comparison of non-target tissue dosimetry. Radiother Oncol 2010, 96:178-184.

18. Stegman LD, Beal KP, Hunt MA, et al: Long-term clinical outcomes of whole-breast irradiation delivered in the prone position. Int J Radiat Oncol Biol Phys 2007, 68:73-81.

19. Ramella S, Trodella L, Ippolito E, et al: Whole-Breast Irradiation: A Subgroup Analysis of Criteria to Stratify for Prone Position Treatment. Med Dosim 2011, Epub ahead of print.

20. Whelan T, Pignol JP, Levine MN, et al: Long-term results of hypofractionated radiation therapy for breast cancer. N Engl J Med 2010 362:513-520.

21. Xa LI, Tai A, Arthur DW, et al: Variability of target and normal structure delineation for breast cancer radiotherapy: An RTOG multi-institutional and multiobserver study. Int J Radiat Oncol Biol Phys 2009, 73:944-951.

22. Whelan TJ, Olivotto I, Acherman I, et al: NCIC-CTG MA.20: An intergroup trial of regional nodal irradiation in eraly breast cancer. J Clin Oncol [abstract] 2011, 29S. abstr LBA 1003.

23. Early Breast Cancer Trialists Collaborative Group (EBCTCG), Clarke M, Collins $R$, Darby $S$, et al: Effect of radiotherapy after breast-conserving surgery on 10-year recurrence and 15-year breast cancer death: meta-analysis of individual patient data for 10801 women in 17 randomised trials. Lancet 2011, 366:2087-2106.

doi:10.1186/1748-717X-7-72

Cite this article as: Leonard et al: Axillary lymph node dose with tangential whole breast radiation in the prone versus supine position: a dosimetric study. Radiation Oncology 2012 7:72

\section{Submit your next manuscript to BioMed Central and take full advantage of:}

- Convenient online submission

- Thorough peer review

- No space constraints or color figure charges

- Immediate publication on acceptance

- Inclusion in PubMed, CAS, Scopus and Google Scholar

- Research which is freely available for redistribution 